\title{
Characteristics of the built environment on GPS- determined bicycle routes used by adolescents
}

\author{
Características do ambiente construído nas rotas de bicicleta determinadas por GPS \\ utilizadas pelos adolescentes
}

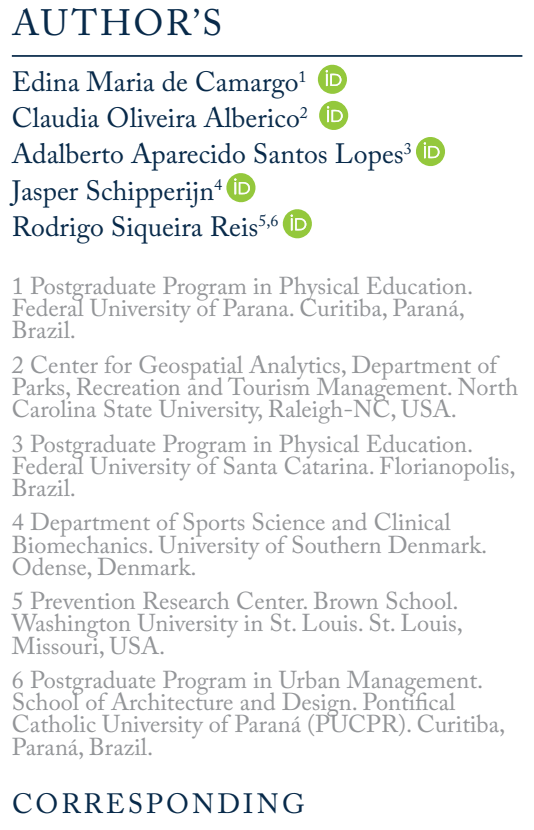

Edina Maria de Camargo

edinacamargo@gmail.com

Rua Coração de Maria, 92, Campus Jardim

Botânico, Curitiba, Paraná, Brasil.

CEP: 80210-132.

\section{DOI}

10.12820/rbafs.24e0106

\section{(cc) BY-NC-SA}

This work is licensed under the Creative Commons Attribution-NonCommercial-ShareAlike 4.0 International License.

\begin{abstract}
The aim of this study was to identify the characteristics of the routes used for cycling according to gender on a sample of adolescents from the city of Curitiba, Brazil. The study was conducted in 2013 with 147 adolescents aged 12 to 17 years, who wore accelerometer and Global Positioning System receivers to assess physical activity and geographic locations. A total of 38 participants (50.0\% girls) presented at least one bicycle route and were included in the analytic sample. A total of 386 routes were identified. Nearly all routes included public transportation facilities, plazas, and parcels with residential, retail, food or recreational land use (> 97.0\%) while bike lanes/paths (62.7\%) and Fitness Zones were less frequent (71.8\%). Bus rapid transit (BRT) stations, parks and vacant lots were the least frequent feature in the routes $(37.3 \% ; 17.1 \%$; and $7.5 \%$, respectively). Routes used by girls had fewer vacant lots $(3.9 \% ; \mathrm{p}=0.001)$ and more residential, retail, food services, and recreational uses (99.6\%; $\mathrm{p}=0.003 ; 99.1 \% ; \mathrm{p}=0.011 ; 98.7 \% ; \mathrm{p}=0.030$, respectively) than those used by boys. The findings suggest that the routes used by adolescents have mixed and diverse land use and girls ride along routes with greater bicycling and service infrastructure and less physical disorder than boys.

Keywords: Physical activity; Adolescent; Bicycling; Geographic Information System; Global Positioning System.

\section{RESUMO}

O objetivo deste estudo foi identificar as características das rotas utilizadas para o uso de bicicleta de acordo com o sexo em uma amostra de adolescentes da cidade de Curitiba, Brasil. O estudo foi realizado em 2013 com 147 adolescentes de 12 a 17 anos, que usaram acelerômetro e receptores de Sistema de Posicionamento Global para avaliar a atividade física e a localização geográfica. Um total de 38 participantes (50,0\% meninas) apresentaram pelo menos uma rota em bicicleta e, por isso, foram incluidos na amostra analítica. Foram identificadas 386 rotas. Quase todas as rotas incluíam meios de transporte público, praças e áreas residencial, comercial, de alimentos ou de lazer (> 97,0\%), enquanto ciclovias (62,7\%) e academias ao ar livre eram menos frequentes $(71,8 \%)$. As estaçôes de ônibus de transporte rápido (BRT), parques e terrenos vazios foram as menos frequentes nas rotas $(37,3 \% ; 17,1 \%$; e 7,5\%, respectivamente). As rotas utilizadas pelas meninas tiveram menos terrenos vazios $(3,9 \% ; p=0,001)$ e mais residenciais, varejo, serviços de alimentação e recreaçẫo (99,6\%; $p=0,003 ; 99,1 \% ; p=0,011 ; 98,7 \% ; p=0,030$, respectivamente) quando comparado com meninos. Os resultados sugerem que as rotas utilizadas pelos adolescentes têm uso misto e diversificado do solo e que meninas trafegam por rotas com maior infraestrutura de bicicleta e serviços e menos terrenos vazios quando comparado com meninos.
\end{abstract}

Palavras-chave: Atividade física; Adolescente; Bicicleta; Sistema de Informaçôes Geográficas; Sistema de Posicionamento Global.

\section{Introduction}

There is a growing body of evidence showing promising and effective interventions to promote physical activity in adolescents ${ }^{1-4}$. Nonetheless, most studies are from high-income countries ${ }^{2-4}$. Research shows that children and adolescents involved in active transportation, for example walking or biking to school, are more likely to reach daily physical activity recommendations but findings on built environment and policy changes that influence adolescents from low- and middle-income countries are nearly inexistent ${ }^{2-5}$.

Moreover, low - and middle-income countries adolescents are exposed to more traffic accidents and higher crime rates ${ }^{4}$, poor access to school facilities ${ }^{5}$ and also experience higher levels of physical inactivity ${ }^{6}$ than those living in high-income countries. Hence, un- 
derstanding where and when adolescents in low- and middle-income countries are more active is a crucial component to improve efforts to reverse the global physical inactivity pandemic ${ }^{7}$.

In Brazil, Alberico et $\mathrm{al}^{8}$ examined four domains (home, school, transport and leisure) in a sample of adolescents and identified locations where physical activity occurred. Although transportation only accounted for few minutes per day, it had the highest proportion of time spent in moderate to vigorous physical activity ${ }^{8}$.

In high-income countries, when investigating the routes for children and adolescents' active transport, results indicate that aesthetics, paths with trees and specific paths for cycling (bike lanes/paths) seem to stimulate cycling ${ }^{7,9}$. On the other hand, perception of intense traffic and negative safety seem to reduce this behavior $^{7,9}$. The influence of unsafety (both for traffic and for crime) as a predictor of reduced time spent in active transport points to the importance of assessing the places where bicycle paths are located ${ }^{7,9}$. These results provide a basis for policy makers, planners and advocacy groups to consider facilitating routes for bicycle use, paying particular attention to constraints ${ }^{7,9}$.

The use of a combination of methods such as GIS (Geographic Information System), accelerometry, and GPS (Global Positioning System) ${ }^{10}$ is particularly relevant for understanding routes used for active commuting among adolescents ${ }^{11-13}$. This understanding allows the planning of more coherent urban environments enabling adolescents' participation and interaction with the community, and improving health in cities ${ }^{12,14,15}$. Thus, the aim of this study was to identify the characteristics of the routes used for cycling according to gender on a sample of adolescents from the city of Curitiba, Brazil.

\section{Methods}

The data used in this study are part of an international multicenter project conducted in 19 countries, known as IPEN (International Physical Activity and Environment Network) ${ }^{16,17}$. With a cross-sectional design, it included household surveys with adolescents aged 12-17 years old, as well as their parents.

All 2395 census tracts (CT) of the city of Curitiba, Brazil were considered as the primary sampling units and screened to determine walkability and income. The operational definition of walkability was the combination of mixed land use, residential density, and street connectivity ${ }^{15}$. In order to maximize variability for environmental and social characteristics, all CT were ranked according to deciles of walkability and income and the two highest and lowest deciles were selected to identify four quadrants (high walkability and high income, high walkability and low income, low walkability and high income, and low walkability and low income). Within each quadrant, eight CT were randomly selected (a total of 32) so the four quadrants were adequately represented ${ }^{16}$.

Twenty-three interviewers (undergraduate and graduate students) conducted the household surveys after receiving 12 hours of training on how to: approach the participants; screen for inclusion criteria; conduct the surveys; complete forms; and identify response rate. Data were collected in the city of Curitiba, Brazil, during the months of August-December 2013 and March-June 2014. However, devices were unavailable during the 2014 period, therefore, this study only presents results from data collected in 2013.

Adolescents aged 12-17 years old, residing in the $\mathrm{CT}$ for at least three months prior to data collection and currently enrolled in school were invited to participate. Those with any physical and/or cognitive limitations were not included. Both adolescent and parent or guardian were asked to complete a survey, and the adolescent was asked to wear a set of devices (Actigraph GT3X or GT3X + accelerometer and QStarz BT - 1000 or BT - 1000X GPS receiver ${ }^{18,19}$ on a belt attached to the hip for seven consecutive days. A total of 147 adolescents wore the devices and 38 presented data relevant to this study (bicycle routes). Participants' characteristics did not show statistical differences between all adolescents wearing the devices ${ }^{8}$ and those with valid bicycle route data.

Once collected, all data were checked for possible satellite reception errors. Logs completed by the participants were reviewed for adequate wear days. Accelerometer and GPS files were merged into the Personal Activity and Location Measurement System (PALMS) platform, aggregating points with the same date and time stamps. All routes with a mode of transport assigned as bicycle (leisure or transport) were included ( $n=386)$, from a final sample of 38 participants, who were described in the initial descriptive analysis. Validated cut points for transport were categorized based on speed: "motor vehicle" ( $>=35 \mathrm{~km} / \mathrm{h}$ ), "bicycle" $(<35 \mathrm{~km} / \mathrm{h}$ and $>10 \mathrm{~km} / \mathrm{h})$ and "walking" ( = $<10 \mathrm{~km} / \mathrm{h})^{20}$. Accelerometers provided data on physical activity and cutpoints used were based on counts: "light" (100 - 2294), "moderate" (2295 - 4011), and 
"vigorous" $(>4012)^{20}$. The routes were considered primary units of analysis for all following analyses.

A 500-meter network buffer ${ }^{21}$ was created around the routes to establish an appropriate area of relevance using ArcGIS 10.3 software. To evaluate the community environment contained around the routes ${ }^{9}$, attributes within the buffers were classified in three different categories: 1) Land use - vacant lots, food, retail, recreational and residential; 2) Leisure - parks, plazas, bike lanes/paths, and fitness zones; 3) Transport - Bus Rapid Transit (BRT) stops, express bus stops, regular/ open bus stops and public transportation (grouping all previous items). The GIS databases from Curitiba were provided by the Institute for Research and IPPUC (Urban Planning of Curitiba).

Gender was self-declared while age was calculated from the date of birth until the date of the interview and classified into three age groups ("12 - 13 years", "14 - 15 years" and "16 - 17 years"). Body mass and height were measured using a scale and digital stadiometer and were used to calculate the BMI (body mass index), normalized into $\mathrm{z}$-scores ${ }^{22}$ and categorized in "underweight", "normal weight", "overweight" and " obese"23, later grouped into normal weight and overweight for analysis purposes. The SES (socioeconomic level) was evaluated with a standardized questionnaire inquiring about possession of items in the residence, education of the head of the household, and presence of a housekeeper $^{24}$. The socioeconomic status was then grouped into "high" (class A), "intermediate" (class B) and "medium-low" (class C and D). Parental level of education was presented in three categories: "< 8 years"; "8 to 12 years"; "Higher education (Bachelor's degree or more)".

Descriptive statistics were used for all variables, and a comparison was made between the routes taken by boys and girls. All analyzes used ArcGIS 10.3 and SPSS 21.0 softwares and the level of significance was set at $5 \%$ for the descriptive statistics (absolute and relative frequencies, chi-square test). When the cells had less than five cases, Fischer's exact test was used.

All participants signed a consent form. In Brazil, the project was titled "Projeto ESPAÇOS Adolescentes" and was thoroughly publicized during data collection. The IRB (Institutional Review Board) at PUCPR (Pontifícia Universidade Católica do Paraná) reviewed and approved this project (\#135-945/2012).

\section{Results}

A total of 38 participants presented at least one bi- cycle route and were included in the analytic sample. Participants were equally distributed by gender $(50.0 \%$ girls), with a mean age of 14.7 years $(\mathrm{SD}=1.65)$ and normal weight status (65.8\%). Parental level of education and SES were predominantly high, with $89.5 \%$ of parents reporting eight years of education or more, and $55.3 \%$ classified as intermediate SES. Most adolescents reported not using a bicycle for transportation (97.4\%). Median wear time for accelerometer and GPS in minutes per day was $785.8(\mathrm{IQR}=149.2)$ and about $60.0 \%$ of the sample presented five or more valid weekdays while $50.0 \%$ had two or more days of weekend data (Table 1).

Presence of community environment attributes within a $500 \mathrm{~m}$ buffer along a total of 386 routes was

Table 1 - Characteristics of adolescents with valid bicycle routes' data in Curitiba, Brazil, $2013(\mathrm{n}=38)$.

\begin{tabular}{|c|c|c|}
\hline \multicolumn{3}{|l|}{ Gender (n; \%) } \\
\hline Male & 19 & 50.0 \\
\hline Female & 19 & 50.0 \\
\hline \multicolumn{3}{|l|}{ Age (years) } \\
\hline Mean & 14.70 & - \\
\hline $\mathrm{SD}$ & 1.65 & - \\
\hline \multicolumn{3}{|l|}{ BMI status $(\mathrm{n} ; \%)$} \\
\hline Normal weight & 25 & 65.8 \\
\hline Overweight & 13 & 34.2 \\
\hline \multicolumn{3}{|l|}{ Parental level of education ( $\mathrm{n} ; \%)$} \\
\hline$<8$ years & 4 & 10.5 \\
\hline 8 to 12 years & 18 & 47.4 \\
\hline Higher education (Bachelor's degree or more) & 16 & 42.1 \\
\hline \multicolumn{3}{|l|}{$\operatorname{SES}(n ; \%)$} \\
\hline A (high) & 8 & 21.0 \\
\hline $\mathrm{B}$ (intermediate) & 21 & 55.3 \\
\hline $\mathrm{C}$ e D (medium-low) & 9 & 23.7 \\
\hline \multicolumn{3}{|l|}{ Report use of bicycle for transport ( $\mathrm{n} ; \%)$} \\
\hline No & 37 & 97.4 \\
\hline Yes & 1 & 2.6 \\
\hline \multicolumn{3}{|l|}{ Wear time for accelerometer/GPS (minutes) } \\
\hline Median & 785.80 & - \\
\hline IQR & 149.20 & - \\
\hline \multicolumn{3}{|l|}{ Number of valid week days ( $n$; \%) } \\
\hline No valid week days & 9 & 23.7 \\
\hline 1 to 4 days & 6 & 15.8 \\
\hline 5 or more days & 23 & 60.5 \\
\hline \multicolumn{3}{|l|}{ Number of valid weekend days ( $\mathrm{n} ; \%)$} \\
\hline No valid weekend days & 11 & 28.9 \\
\hline 1 day & 8 & 21.1 \\
\hline 2 or more days & 19 & 50.0 \\
\hline
\end{tabular}

$\mathrm{SD}=$ standard deviation; $\mathrm{BMI}=$ body mass index; $\mathrm{SES}=$ socioeconomic status; GPS = Global Positioning System; IQR = Interquartile range. 


\section{Routes containing attributes}

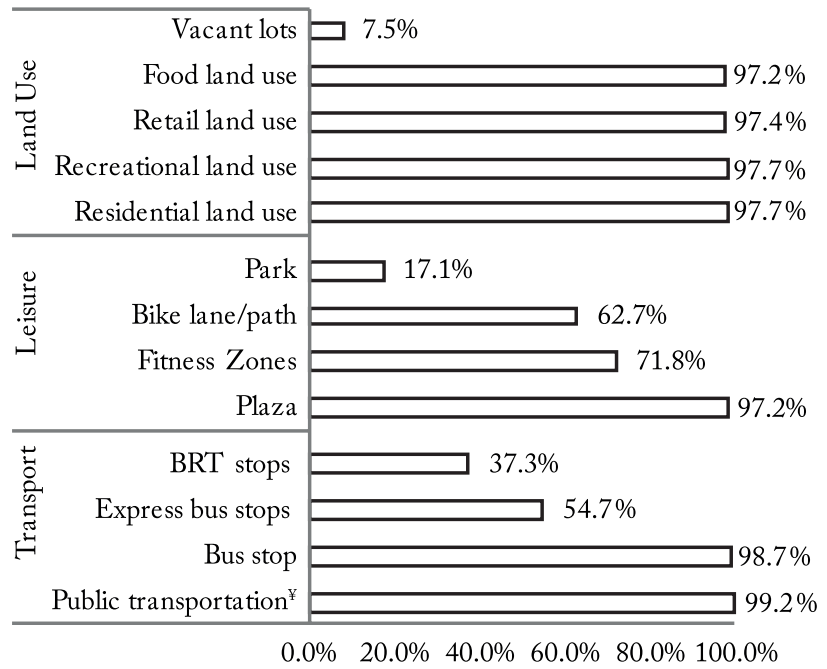

Figure 1 - Presence of community environment attributes along bycicling routes used by adolescents from Curitiba, Brazil, 2013 (n $=386$ ).

BRT = Bus Rapid Transit; $¥=$ All types of public transportation (bus stop, express bus station and BRT station) identified. BRT stations, parks and vacant lots were present in fewer routes than other variables $(37.3 \%$; $17.1 \%$; and $7.5 \%$, respectively). Public transportation, plazas, and parcels with residential, retail, food or recreational land use were present in nearly all routes whereas Fitness Zones (71.8\%) and bike lanes/paths (62.7\%) were present in the majortity of routes (Figure 1).

Figure 2 presents community environment attributes available along the routes used stratified by gender. Along the routes used by girls, vacant lots were less frequent (3.9\%; $\mathrm{p}=0.001)$, whereas residential, retail and food services were more frequent $(99.6 \% \mathrm{p}=0.003$; $99.1 \% \mathrm{p}=0.011 ; 98.7 \% \mathrm{p}=0.030$, respectively), when compared to the routes used by boys.

\section{Discussion}

The study findings suggest that bycicling routes used by adolescents (transport and leisure) included mixed and diverse land uses (e.g. public transportation, residential, retail and recreational facilities) and varied by gender with girls riding in routes with greater bycicling in-

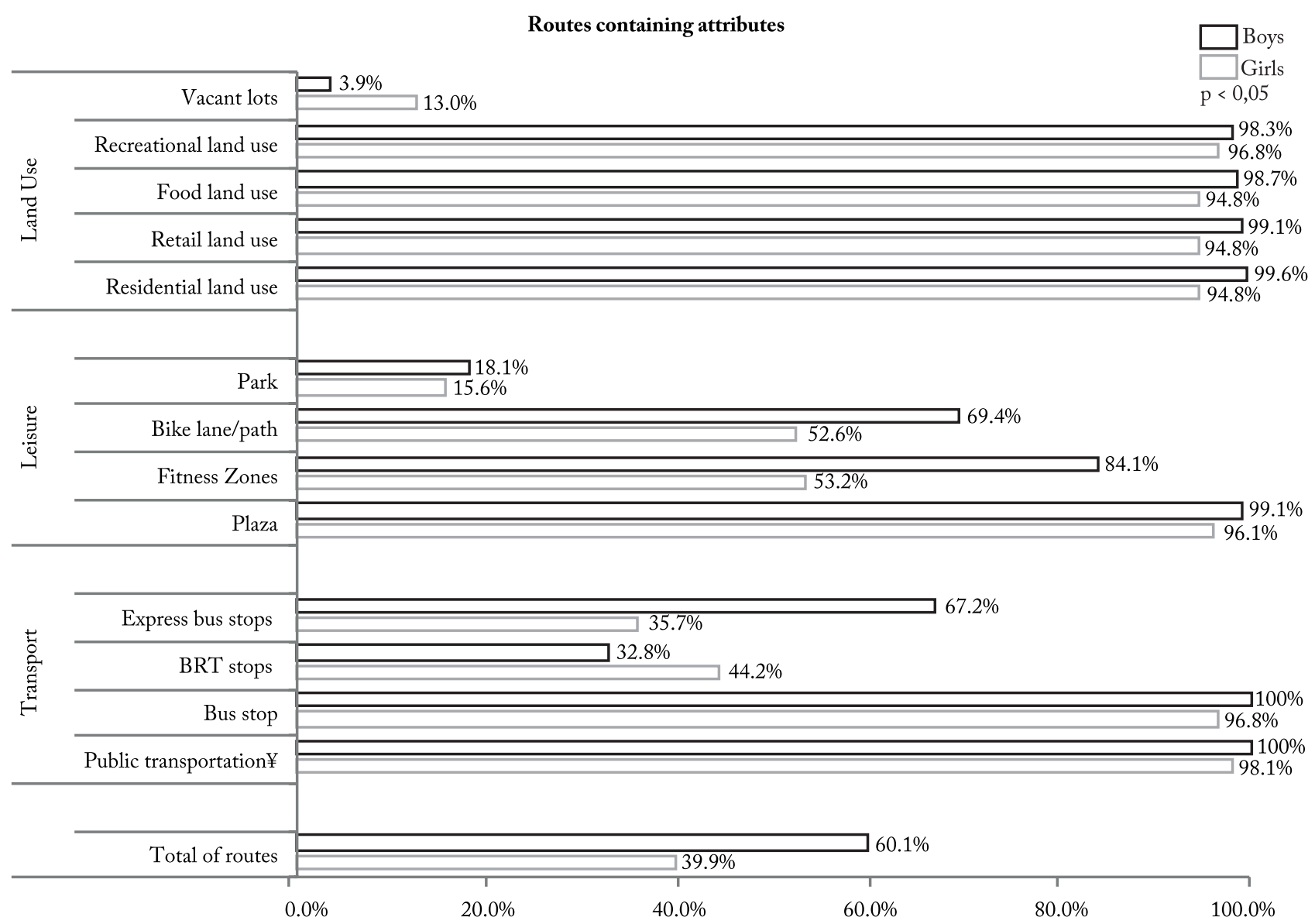

Figure 2 - Presence of Community environment attributes along bycicling routes used by adolescents, according to gender from Curitiba, Brazil, $2013(\mathrm{n}=386)$.

BRT = Bus Rapid Transit; $¥$ = All types of public transportation grouped (bus stop, express bus station and BRT station) 
frastructure and less physical disorder (e.g. vacant lots). Several community environment characteristics were identified along the routes, however, BRT stations, par$\mathrm{ks}$, and vacant lots were present in fewer routes compared to other variables. When considering all types of public transportation, most routes had bus stops (regular or express buses) and BRT stations (99.2\%). After public transportation, the most frequent structures were plazas and lots for residential, retail, food and recreation uses.

Curitiba, Brazil has higher density and walkability levels when compared to cities from high-income countries $^{25}$. However, although access to bicycling infrastructure has been associated with higher chance of using bicycle $^{11,21}$ the study sample showed a lower level of bycicling as compared to less compact and more economic developed cities indicating that other social and physical aspect of the environment may influence when and how often adolescents ride their bicycles in the city ${ }^{11,21}$. In this sample, adolescents' parents had a predominant high education level and socioeconomic status and resided in places with better walkability and higher neighborhood income, important factors to increase the chance of engagement in leisure physical activity ${ }^{25}$. Furthermore, aesthetics, tree coverage and designated paths for cycling (bike lanes/paths) may increase bycicling whereas perception of intense traffic and negative safety seem to prevent this behavior ${ }^{26}$. Hence, improving perceptions of safety along with access to adequate bycicling infrastructure should be prioritized ${ }^{26}$.

The routes used by boys and girls have similarities with frequent presence of public transportation and recreation (e.g. plazas and parks - Figure 2). However, girls cycled on routes with fewer vacant lots $(3.9 \%$ versus $13.0 \% ; \mathrm{p}=0.001)$ and in areas with greater residential and commercial use than the routes used by boys. Additionally, adolescents in this study chose to ride bicycles even when public transportation was available in $100 \%$ of the routes $(p=0.010)$ indicating that bycicling could be a preferable mode of transportation. Boys chose routes with fewer bike lanes or paths available $(52.6 \% ; \mathrm{p}=0.001)$ when compared to girls. Some of these findings may be due to recent social and urban planning changes in the city of Curitiba. There has been an increase in the complaints on the quality and safety of the public transportation system ${ }^{26,27}$. Additionally, many of the bycicling paths have been designed for recreational use and not for transporta$\operatorname{tion}^{26,27}$. The combination of these characteristics may help understand these findings.
Although the small sample size $(n=38)$ may raise concerns about both external validity and sample power, our primary unit of analysis were 368 routes captured by GPS receivers. Therefore, the analysis was not affected. There is a need to increase the number of bicycle users to potentiate promotion of physical activity especially through active transport. The school and the community can serve as a driving element of these initiatives, given the evidence of effectiveness of the promotion of livelihood assets from the school environment and community ${ }^{28,29}$.

The present study only verified the characteristics of the environment along the routes. Thus there is no possibility of investigating causal relation between the frequency of use of bicycles and the routes investigated. Future studies could investigate which alternative routes are available to try to identify preferences. Nonetheless, it is possible to affirm that regarding the main feature of the routes used by boys and girls, adolescents used routes with houses and businesses more often, and girls chose routes with fewer vacant lots when compared to boys. Helping teens to find safer routes and promoting group rides to school could be an interesting approach to maximize use of active transportation. Interventions may include limiting motorized traffic in school zones during before and after classes and traffic education campaigns, with the encouragement of authorities and the planning and evaluation public policies ${ }^{30,31}$.

The limitations from the present study must be considered when interpreting the results. The study sample is not representative of adolescents in the city of Curitiba, since the study was not designed to represent the entire population. Adolescents lived in census tracts intentionally selected to allow comparisons between characteristics of walkability and income. Nevertheless, because the selection process took such variables into account, they could have determined some of the characteristics of the routes. The use of bicycle is low among adolescents in the city of Curitiba, Brazil. Although the city has invested in infrastructure for cycling in recent years, there were few users in this sample.

Studies show that the accessibility, availability and attractiveness of structures for physical activity in the neighborhood can significantly increase the likelihood of adolescents becoming active $e^{30,31}$. Educational activities, walking mobility campaigns, skateboarding, rollerblading and cycling should be encouraged so that such activities are carried out not only in leisure, but on a daily basis, increasing the physical activity levels of boys and 
girls. Therefore, information about the routes available for bicycle use, as well as the neighborhood and structures available for physical activity, safety information regarding the routes and even traffic education can influence parents and teens to join active transport, given the evidence of effectiveness of the promotion of active lifestyles from the school and community environment.

The findings of this study can conclude that the routes taken by adolescents while cycling were through environments with public transportation, parks, houses, shops and spaces for recreation. A bicycle path was not present in all routes (only 62\%) and yet, even with public transportation available in $100 \%$ of the routes, participants still chose to use a bicycle.

Assessing bicycling characteristics along routes used for commuting to and from school is an important step for increasing active commuting. Policy makers, planners and activists should consider the routes that facilitate bicycle use by adolescents, considering the results of this study such as presence of public transportation, parks and spaces designed for residential, retail, food and recreation, bike paths and trails.

\section{Conflict of interest declaration}

The authors declare no conflict of interest.

\section{Author's contributions}

Camargo EM, responsible for all aspcts of the work. Alberico CO, writing the manuscript and geospatial analysis. Lopes AAS, writing the manuscript and geospatial analysis. Schipperijn J, relevant critical content review. Reis RS, relevant critical content review.

\section{Acknowledgement}

This work was supported by a grant (No 5R01HL111378-02) from the National Institutes of Health (NIH).

\section{References}

1. Guthold R, Stevens GA, Riley LM, Bull FC. Global trends in insufficient physical activity among adolescents: a pooled analysis of 298 population-based surveys with 1.6 million participants. Lancet Child Adolesc Health. 2020;4:23-35.

2. Loh VHI, Veitch J, Salmon J, Cerin E, et al. Built environment and physical activity among adolescents: the moderating effects of neighborhood safety and social support. Int J Behav Nutr Phys Activity. 2019;16 (1):132-9.

3. Sallis JF, Conway TL, Cain KL, Carlson JU, et al. Neighborhood built environment and socioeconomic status in relation to physical activity, sedentary behavior, and weight status of adolescents. Prev Med. 2018;110:47-54.

4. Audrey S, Batista-ferrer H. Healthy urban environments for children and young people: A systematic review of intervention studies. Health Place. 2015;36:97-117.
5. Knuth AG, Hallal PC. School environment and physical activity in children and adolescents: systematic review. Rev Bras Ativ Fís Saúde. 2012;17(6):463-73.

6. Hallal PC, Andersen LB, Bull FC, Guthold R, Haskell W, Ekelund U, et al. Global physical activity levels: surveillance progress, pitfalls, and prospects. Lancet. 2012.380 (9838):247-57.

7. Grow HM, Saelens BE, Kerr J, Durant NH, Normam GJ, Dallis JF, et al. Where are youth active? Roles of proximity, active transport, and built environment. Med Sci Sports Exerc. 2008;40(12):2071-9.

8. Alberico CO, Schipperijn J, Reis RS. Use of global positioning system for physical activity research in youth: ESPAÇOS Adolescentes, Brazil. Prev Med. 2017.103;S59-S65.

9. Dessing D, de Vries SI, Hegeman G, Verhagen E et al. Children's route choice during active transportation to school: difference between shortest and actual route. Int J Behav Nutr Phys Act.2016;13:48.

10. Duncan MJ, Badland HM, Mummery WK. Applying GPS to enhance understanding of transport-related physical activity. J Sci Med Sport. 2009;12:549-56.

11. Macridis $S$, Bengoechea EG.Adoption of Safe Routes to School in Canadian and the United States Contexts: Best Practices and Recommendations. J Sch Health.2015;85: 558-66.

12. Lee C, Li L. Demographic, physical activity, and route characteristics related to school transportation: An exploratory study. Am J Heal Promot. 2014;28:77-89.

13. Mccrorie PR, Fenton C, Ellaway A. Combining GPS, GIS, and accelerometry to explore the physical activity and environment relationship in children and young people - a review. Int J Behav Nutr Phys Act. 2014;11:93.

14. Bürgi R, Tomatis L, Murer K, Bruin ED. Localization of physical activity in primary school children using accelerometry and global positioning system. PLoS One. 2015; 10:1-13.

15. Sallis JF, Cervero RB, Ascher W, Henderson KA, Kraft MK, Kerr J. An Ecological approach to creating active living communities. Annu Rev Public Health. 2006;27:297-322.

16. Hino AAF, Rech CR, Gonçalves PB, Hallal PC et al . Projeto ESPAÇOS de Curitiba, Brasil: aplicabilidade de métodos mistos de pesquisa e informações georreferenciadas em estudos sobre a atividade física e ambiente construído. Rev Panam Salud Publica. 2012;32:226-33.

17. Kerr J, Sallis JF, Owen N, De Bourdeaudhuij I, Cerin E, Sugiyama $\mathrm{T}$ et al. Advancing Science and Policy through a Coordinated International Study of Physical Activity and Built Environments: IPEN Methods. J Phys Act Health.2013;10:581-601.

18. Laguna M, Ruiz JR, Gallardo C, Gracia-Pastor T, Lara MT, Aznar S. Obesity and physical activity patterns in children and adolescents. J Pediatr Child Heal. 2013;49: 942-49.

19. Cerin E, Cain K1, Conway TL, Van Dyck D, Hinckson E, Schipperijn J et al. Neighborhood Environments and Objectively Measured Physical Activity in 11 Countries. Med Sci Sports Exerc. 2014;46(12):2253-64.

20. Carlson JA, Jankowska MM, Meseck K, Godbole S, Natarajan G, Raab F et al. Validity of PALMS GPS Scoring of Active and Passive Travel Compared to SenseCam. Med Sci Sports Exerc.2015;47(3):662-7.

21. Madsen T, Schipperijn J, Christiansen LB, Christiansen LB, et al. Developing suitable buffers to capture transport cycling behavior. Front Public Healh.2014;2:61. 
22. Cole TJ, Bellizzi MC, Flegal KM, Dietz WH. Establishing a standard definition for child overweight and obesity worldwide: International Survey. Bmj. 2000;320(7244):1240-3.

23. Conde WL, Monteiro CA. Body mass index cutoff points for evaluation of nutritional status in Brazilian children and adolescents. J Pediatr.2006;82(4):266-72.

24. Associação Brasileira de Empresas de Pesquisa - ABEP. Critério de Classificação Econômica Brasil. São Paulo: Associação Brasileira de Empresas de Pesquisa. 2013.

25. Reis RS, Hino AAF, Rech CR, Kerr J, Hallal PC. Walkability and Physical Activity: Findings from Curitiba, Brazil. Am J Prev Med.2013;45:269-75.

26. Schantz P. Exploring bikeability in a suburban metropolitan area using the Active Commuting Route Environment Scale (ACRES). Int J Environ Res Public Health. 2014; 11:8276-300.

27. Ma L, Dill J. Do Peoples Perceptions of Neighborhood Bikeability Match 'Reality”? J Transp Land Use.2017;10:1-8.
28. Ribeiro IC, Parra DC, Hoehner CM, Soares J et al. Schoolbased physical education programs: evidence-based physical activity interventions for youth in Latin America. Glob Health Promot. 2010;17:5-15.

29. Hoehner CM, Ribeiro IC, Parra DC, Reis RS et al. Physical activity interventions in Latin America: Expanding and classifying the evidence. Am J Prev Med. 2013;44:e31-e40.

30. Oreskovic NM, Perrin JM, Robinson AI, Locascio JJ et al. Adolescents' use of the built environment for physical activity. BMC Public Health. 2015;15:1596.

31. Ferrari GLM, Victo ER, Ferrari TK, Solé D. Active transportation to school for children and adolescents from Brazil: a systematic review. Rev. Bras. Cineantropom. Desempenho Hum. 2018;20(4):406-14.

Receivde: $17 / 11 / 2019$

Approved: 22/06/2020

\section{Quote this article as:}

